\title{
Effects of Postharvest Onion Curing Parameters on the Development of Sour Skin and Slippery Skin in Storage
}

\author{
B. K. Schroeder and J. L. Humann, Washington State University, Pullman 99164; and L. J. du Toit, Washington State University \\ Mount Vernon NWREC, Mount Vernon 98273
}

\begin{abstract}
Schroeder, B. K., Humann, J. L., and du Toit, L. J. 2012. Effects of postharvest onion curing parameters on the development of sour skin and slippery skin in storage. Plant Dis. 96:1548-1555.

The influence of postharvest curing temperature and duration on development of slippery skin (caused by Burkholderia gladioli pv. alliicola) and sour skin (caused by B. cepacia) in onion (Allium cepa) bulbs during storage was evaluated by inoculating bulbs of the storage cultivars 'Redwing' and 'Vaquero' with each of the pathogens after harvest, curing the bulbs at $25,30,35$, or $40^{\circ} \mathrm{C}$ for 2 or 14 days, and storing the bulbs at $5^{\circ} \mathrm{C}$ for 1,2 , or 3 months. Noninoculated bulbs and bulbs injected with sterile water served as control treatments. The onion bulbs were from drip-irrigated, commercial onion crops grown in the semiarid Columbia Basin of central Washington in 2009 and 2010. Each bulb was cut through the point of inoculation from the neck to the basal plate to assess severity of bulb rot (percentage of cut bulb surface area with bacterial rot symptoms) after 1,2 , or 3 months of storage. Bulb rot severity in the 2009-10 and 2010-11 trials was negligible for noninoculated bulbs (mean of 4.0 and $4.5 \%$, respectively) and bulbs injected with water (6.2 and $10.1 \%$, respectively) compared with bulbs inoculated with $B$. cepacia (34.6 and $39.8 \%$, respectively) and $B$. gladioli pv. alliicola (20.7 and $27.4 \%$, respectively). Bulbs inoculated

inoculated with $B$. gladioli pv. alliicola, even though a 10 -fold greater inoculum concentration was used for $B$. gladioli pv. alliicola, demonstrating the more aggressive nature of $B$. cepacia compared with B. gladioli pv. alliicola. Severity of bulb decay caused by B. cepacia or B. gladioli pv. alliicola was affected significantly $(P<0.05)$ by season (trial), cultivar, curing temperature, curing duration, and storage duration, with significant interactions among these factors. In both trials and for both pathogens, bulb rot was significantly more severe the greater the curing temperature and the severity of bulb rot was significantly greater when bulbs were cured for 14 versus 2 days prior to cold storage. Overall, the severity of bulb rot was greater with a longer duration of storage after curing. This increase in bulb rot severity, which resulted from an increase in curing temperature and duration, was significantly greater for Vaquero than Redwing and significantly greater for bulbs inoculated with $B$. cepacia than B. gladioli pv. alliicola. The results suggest that postharvest curing at temperatures $<35^{\circ} \mathrm{C}$ for a limited duration can significantly reduce the severity of sour skin or slippery skin in storage.
\end{abstract} with $B$. cepacia developed significantly more severe rot than those
Production of storage onion (Allium cepa L.) results in $>\$ 900$ million in farm receipts from $>44,500$ ha grown annually in the United States, with approximately $66 \%$ of the production occurring in the western United States (1). The major postharvest issues for storage onion are shrinkage and storage rots (3). Shrinkage results from a loss of moisture and, subsequently, bulb size and weight during storage. Onion storage rots result from infection of the bulbs by any of the more than 26 pathogens known to cause bulb rots (17). In most years, a low level of onion bulb rot $(<1 \%)$ can be expected but significant economic losses occur sporadically (up to $100 \%$ losses in individual storage facilities; 12). Numerous bacteria, filamentous fungi, and a yeast can cause onion bulb rots in storage, individually and in combination, and it is often difficult to determine the specific causal agent or agents of a particular storage rot outbreak (17; B. K. Schroeder and L. J. du Toit, unpublished).

A summary of inspected onion shipments into New York State from 1972 to 1984 suggested that $16 \%$ of the shipments contained onion bulbs exhibiting storage rots (6). Bacterial storage rots were detected in $>50 \%$ of the symptomatic shipments, of which $35 \%$ contained unacceptable incidences of storage rot $(>2 \%)$. This translated to $100 \%$ losses for producers because of failure to meet

Corresponding author: B. K. Schroeder, E-mail: bschroeder@wsu.edu

* The $\boldsymbol{e}$-Xtra logo stands for "electronic extra" and indicates Figure 1 appears in color online.

Accepted for publication 10 May 2012.

http://dx.doi.org/10.1094/PDIS-02-12-0117-RE

(C) 2012 The American Phytopathological Society
United States number 1 grade standards. Data on the current prevalence of onion storage rots in the various regions of storage onion production in the United States are not readily available but empirical evidence indicates that onion growers and packers still incur sporadic economic losses to storage rots (8). Twelve bacteria are documented to cause onion bulb rots, including Burkholderia cepacia, B. gladioli pv. alliicola, Dickeya chrysanthemi, Enterobacter cloacae, Erwinia rhapontici, Pantoea agglomerans, P. allii, $P$. ananatis, Pectobacterium carotovorum subsp. carotovorum, Pseudomonas aeruginosa, $P$. marginalis pv. marginalis, and $P$. viridiflava $(3,17)$. These bacteria can produce similar symptoms in onion bulbs, making it difficult, if not impossible, to determine the causal agent or agents by visual inspection alone.

B. cepacia, causal agent of sour skin (5), is a soil-inhabiting, Gram negative, obligate aerobic bacterium that is commonly present in decaying plant tissue and readily spread through irrigation water (18). B. cepacia can infect onion plants in the field, causing light-brown lesions on leaves and a watery rot in the neck of onion plants $(10,11)$. Bulb symptoms usually only develop in storage (17). Infected onion bulbs develop slimy, yellow, internal fleshy scales. B. cepacia produces macerating enzymes that degrade onion bulb scales but infection typically is limited to one or a few scales within a bulb. There is no evidence of bulb-to-bulb spread of the pathogen in storage. Field symptoms can be promoted by overhead irrigation (17), excessive irrigation $(17,18)$, and excessive nitrogen fertilization (17). Wounding, moist conditions at harvest, and late-season field temperatures $>30^{\circ} \mathrm{C}$ can also increase the severity of sour skin. In addition to infecting leaves through wounds, B. cepacia can infect onion leaves during field topping, and infection can then progress into the bulb from the leaf. This is enhanced by wet weather close to harvest (11). Dry field conditions before and during harvest are optimal to prevent dispersal of the bacterium among plants via contaminated farm machinery. No 
resistant cultivars or chemical control measures are available for the control of sour skin in storage (17).

B. gladioli pv. alliicola, causal agent of slippery skin, is present in many, if not all, storage onion production areas worldwide $(4,17)$. This Gram negative bacterium enters plant tissues via wounds, causing onion bulb rot without external symptoms other than softening of the neck of some infected bulbs (4). Bulb rot symptoms include creamy yellow or yellow-brown, water-soaked discoloration of one or two inner fleshy scales. Infection by $B$. gladioli pv. alliicola typically progresses from the top of the infected fleshy scale toward the basal plate, from which infection can spread to adjacent scales (17). Scales with advanced stages of infection may dry out, giving the bulb a shriveled appearance. The name "slippery skin" is derived from the fact that the center scales of an infected bulb "slip" out the top of the bulb if pressure is applied to the base of the bulb. However, this is not always evident in bulbs infected with $B$. gladioli pv. alliicola. High temperatures and wet conditions promote slippery skin (17).

Control measures for B. cepacia and B. gladioli pv. alliicola include the use of furrow or drip irrigation instead of overhead irrigation, when feasible, and avoiding harvest of bulbs soon after lateseason rains $(3,12,17)$. In addition, careful crop management at harvest can be critical, including growing bulbs under conditions that promote even maturation across the field, harvesting bulbs soon after lodging or "tops down" (leaves fallen after the necks have dried), and drying onion bulbs promptly after harvest $(3,17)$. Onion bulbs may be cured naturally under field conditions or using postharvest curing. Curing is a crucial step to conditioning the bulbs for long-term storage and results in tight outer wrapper scales on the bulbs. This reduces moisture loss and shrinkage during storage, and limits the movement of fungal and bacterial pathogens from the neck into the fleshy bulb scales (3).

The semiarid environment of most onion-production regions in the western United States enables bulbs to be field cured, beginning with termination of irrigation when 70 to $90 \%$ of the plants have lodged. The plants are then undercut and the leaves removed by "topping". The topped bulbs are then left in the field to dry. In some areas, field curing is followed by postharvest curing in storage facilities (12). Postharvest curing begins with the movement of either ambient air $\left(24\right.$ to $27^{\circ} \mathrm{C}$ or higher, depending on weather conditions) through the storage facility for 2 to 3 weeks or heated air ( 29 to $35^{\circ} \mathrm{C}$ or higher) for 2 days or longer. Curing is continued until the air exiting the storage facility reaches $70 \%$ relative humidity. The temperature is then gradually decreased 1 to $5^{\circ} \mathrm{C} /$ day until the temperature reaches 3 to $5^{\circ} \mathrm{C}(3,12)$. Although higher curing temperatures are used in some storage facilities to dry bulbs quickly and reduce the potential for Botrytis spp. to colonize and rot onion bulbs (3), higher temperatures also promote the growth of bacterial pathogens such as B. cepacia and B. gladioli pv. alliicola (9), and the fungal pathogen Aspergillus niger (17).

Schroeder and du Toit (14) evaluated the effects of postharvest curing temperature, curing duration, and duration of storage of onion bulbs on severity of Enterobacter bulb decay caused by Enterobacter cloacae. The results indicated that keeping the postharvest curing temperature $<35^{\circ} \mathrm{C}$, regardless of curing duration (2 versus 14 days), minimized the severity of Enterobacter bulb decay. The objectives of this study were to determine how postharvest curing temperature, curing duration, and duration of storage of onion bulbs influence severity of sour skin and slippery skin in order to help onion stakeholders utilize postharvest curing parameters more effectively to reduce losses to B. cepacia and B. gladioli pv. alliicola.

\section{Materials and Methods}

Experimental design and source of onion bulbs. Each trial was set up as a randomized complete block design with a factorial combination of two onion cultivars ('Redwing' and 'Vaquero', representing common red and yellow storage cultivars grown in the Pacific Northwest region of the United States), four inoculation treatments (B. cepacia, B. gladioli pv. alliicola, water, and non- inoculated bulbs), four curing temperatures $\left(25,30,35\right.$, and $\left.40^{\circ} \mathrm{C}\right)$, two curing durations ( 2 and 14 days), and three storage durations $(1,2$, and 3 months). Four replicates of five onion bulbs were used for each treatment combination. The trial was carried out in the 2009-10 storage season and repeated in the 2010-11 storage season. The Redwing and Vaquero bulbs were harvested in 2009 and 2010 from commercial onion crops grown in the semiarid Columbia Basin of central Washington using production practices typical for this region (12). The bulbs ranged from 5.0 to $7.5 \mathrm{~cm}$ in diameter and were removed from the field manually after each crop had been topped mechanically. The 2009 and 2010 crops of each cultivar were grown by the same producer, using drip irrigation.

Onion bulb inoculations. B. cepacia strain BcWSU1 and $B$. gladioli pv. alliicola strain BgWSU1 (15) were each grown overnight in $5 \mathrm{ml}$ of nutrient broth (19) at $28^{\circ} \mathrm{C}$ with agitation. A $0.5 \mathrm{ml}$ aliquot of the culture was then added to $250 \mathrm{ml}$ of nutrient broth and incubated overnight at $28^{\circ} \mathrm{C}$ with agitation. Cells were harvested by centrifugation $(48,800 \times g$ for $10 \mathrm{~min})$, washed with sterile distilled water, and resuspended in sterile distilled water to an optical density at $600 \mathrm{~nm}$ of 0.3 (approximately $1 \times 10^{8}$ $\mathrm{CFU} / \mathrm{ml}$ ). Each suspension was diluted 100 -fold to approximately $1 \times 10^{6} \mathrm{CFU} / \mathrm{ml}$ for BgWSU1 and 1,000-fold to approximately $1 \times$ $10^{5} \mathrm{CFU} / \mathrm{ml}$ for BcWSU1. A 10 -fold lower concentration of inoculum was used for $B$. cepacia versus $B$. gladioli pv. alliicola inoculations because previous research demonstrated that the former is a more aggressive bulb rot pathogen than the latter (15). The inoculum for each pathogen was dispensed into sterile test tubes. A $0.5 \mathrm{ml}$ aliquot of inoculum or water was injected into each bulb at the shoulder, as described by Schroeder and du Toit (14). A separate tube of inoculum and a new, sterile syringe were used for each replicate of five onion bulbs. Bulbs injected with sterile water served as one control treatment, and noninoculated bulbs served as the second control treatment to assess the incidence of natural infection of each commercial bulb lot by bacterial pathogens.

Bulb curing and storage. After inoculation, four replicate sets of 15 onion bulbs for each cultivar and inoculation treatment were placed in nylon mesh onion bags in incubators set at $25,30,35$, or $40^{\circ} \mathrm{C}$. The bulbs were cured for 2 or 14 days with a fan circulating air within each chamber. The temperature in each incubator was then reduced by $2.5^{\circ} \mathrm{C}$ daily to reach $5^{\circ} \mathrm{C}$ after curing. The bulbs were stored at $5^{\circ} \mathrm{C}$ for 1,2 , or 3 months. After storage, five bulbs were removed from each replicate bag and evaluated for severity of bulb rot. Each onion bulb was sliced through the center of the inoculation site from the neck to the basal plate, and the cut surface area of the fleshy scales was rated visually for severity of bulb decay (percentage of the cut surface area of the fleshy scales showing symptoms typical of bacterial rot).

Statistical analyses. Bulb rot severity ratings were subjected to analyses of variance (ANOVAs) using SAS (Version 9.2; SAS Institute), with trial (year) and replication as random effects and inoculation treatment, cultivar, curing temperature, curing duration, and duration of storage as fixed effects. In each trial, bulb rot severity ratings for the two control treatments were extremely low compared with ratings for bulbs inoculated with B. cepacia and $B$. gladioli pv. alliicola (Table 1). Therefore, the two control treatments were not included in the ANOVA to avoid extremely heterogeneous variances, and the data were analyzed separately for each pathogen because of significant differences in results for the two pathogens. Data for the inoculated bulbs were subjected to $\log$ or square root transformations (Table 2) because of heterogeneous variances or non-normal distribution of residuals. Results were analyzed separately for each trial-pathogen combination because of a significant trial main effect and significant interactions of trial with other factors in the ANOVAs. Mean bulb rot severity ratings were compared using Fisher's protected least significant difference at $P<0.05$. Pearson's correlation coefficients were calculated overall and by cultivar for mean bulb rot severity ratings in the 2009-10 versus the $2010-11$ storage trials. 


\section{Results}

Inoculation of onion bulbs with B. cepacia and B. gladioli pv. alliicola. Inoculation of Redwing and Vaquero onion bulbs with $B$. cepacia strain BcWSU1 at $1 \times 10^{5} \mathrm{CFU} / \mathrm{ml}$ and B. gladioli $\mathrm{pv}$. alliicola strain BgWSU1 at $1 \times 10^{6} \mathrm{CFU} / \mathrm{ml}$ increased the incidence and severity of bacterial storage rot in each trial compared with noninoculated bulbs or bulbs injected with sterile water, re-

Table 1. Incidence and severity of bacterial bulb decay of 'Redwing' and 'Vaquero' onion harvested from crops grown in Washington State in 2009 and 2010, inoculated with Burkholderia cepacia and B. gladioli pv. alliicola, subjected to different postharvest curing parameters, and stored for 1,2 , or 3 months $^{\mathrm{a}}$

\begin{tabular}{lrr}
\hline & \multicolumn{2}{c}{ Mean \pm standard error ${ }^{\mathbf{b}}$} \\
\cline { 2 - 3 } Trial, treatment ${ }^{\mathbf{c}}$ & Incidence $(\%)$ & \multicolumn{1}{c}{ Severity of bulb rot } \\
\hline 2009-10 & & \\
B. cepacia & $89.48 \pm 0.31$ & $34.6 \pm 0.9(0-100)$ \\
B. gladioli pv. alliicola & $88.85 \pm 0.01$ & $20.7 \pm 0.6(0-100)$ \\
Sterile water & $6.15 \pm 0.01$ & $1.3 \pm 0.2(0-100)$ \\
Noninoculated & $3.96 \pm 0.01$ & $1.0 \pm 0.2(0-100)$ \\
2010-11 & & \\
B. cepacia & $89.17 \pm 0.01$ & $39.8 \pm 1.0(0-100)$ \\
B. gladioli pv. alliicola & $91.15 \pm 0.01$ & $27.4 \pm 0.7(0-100)$ \\
Sterile water & $10.10 \pm 0.01$ & $4.4 \pm 0.6(0-100)$ \\
Noninoculated & $4.48 \pm 0.01$ & $2.7 \pm 0.5(0-100)$ \\
\hline
\end{tabular}

a Bulbs were cured at temperatures ranging from 25 to $40^{\circ} \mathrm{C}$ for 2 or 14 days, and then stored at $5^{\circ} \mathrm{C}$ for 1,2 , or 3 months. Four replications of five onion bulbs were inoculated per treatment combination per year. Each bulb was cut down the center from the neck to the basal plate, through the inoculation site.

${ }^{\mathrm{b}}$ Incidence $=$ percentage of bulbs with bacterial storage rot symptoms and Severity $=$ percentage of the cut surface area of fleshy scales showing symptoms of bulb decay.

${ }^{c}$ A $0.5 \mathrm{ml}$ suspension of B. cepacia $\left(10^{5} \mathrm{CFU} / \mathrm{ml}\right)$, B. gladioli pv. alliicola $\left(10^{6} \mathrm{CFU} / \mathrm{ml}\right)$, or water was injected into the shoulder of each onion bulb immediately after harvest. A lower inoculum dose was used for $B$. cepacia than for $B$. gladioli pv. alliicola because the former is significantly more aggressive than the latter as a bulb rot pathogen. Noninoculated bulbs were not injected. gardless of postharvest curing parameters and duration of storage (Table 1). B. cepacia caused water soaking of internal fleshy scales of the bulbs, tissue maceration, and necrosis that were typical of sour skin (Fig. 1B). B. gladioli pv. alliicola caused water soaking of fleshy scales and necrosis typical of slippery skin (17). The scales of bulbs inoculated with B. gladioli pv. alliicola dried out and collapsed with increasing duration of storage (Fig. 1C). This was not observed in bulbs inoculated with $B$. cepacia. For both pathogens, symptoms developed primarily in the upper half of each inoculated bulb, and progressed toward the basal plate with increasing duration of storage. Severity of bulb rot in the 2009-10 and 2010-11 trials averaged $34.6 \pm 0.9 \%$ (mean \pm standard error) and $39.8 \pm 1.0 \%$, respectively, for bulbs inoculated with $B$. cepacia, compared with $20.7 \pm 0.6$ and $27.4 \pm 0.7 \%$, respectively, for bulbs inoculated with $B$. gladioli pv. alliicola (Table 1). In comparison, the severity of bulb rot for noninoculated bulbs was $1.0 \pm 0.2$ and $2.7 \pm 0.5 \%$ in the $2009-10$ and $2010-11$ trials, respectively, and $1.3 \pm 0.2$ and $4.4 \pm 0.6 \%$, respectively, for bulbs injected with sterile water (Table 1). The incidence of natural infection of the four bulb lots from the grower-cooperators' crops was very low, as demonstrated by the noninoculated bulbs $(3.96 \pm$ 0.01 and $4.48 \pm 0.01 \%$ in $2009-10$ and $2010-11$, respectively; Table 1). Injection of bulbs with sterile water in each of the 2009 10 and 2010-11 trials increased the incidence of bulb rot slightly to $6.15 \pm 0.01$ and $10.10 \pm 0.01 \%$, respectively, but far less than that of bulbs injected with B. cepacia at $89.48 \pm 0.01$ and $89.17 \pm$ $0.01 \%$, respectively, or B. gladioli pv. alliicola at $88.85 \pm 0.01$ and $91.15 \pm 0.01 \%$, respectively (Table 1 ).

2009-10 trial: B. cepacia. The severity of sour skin for bulbs inoculated with $B$. cepacia was affected significantly by the main effects of cultivar $(P=0.0001)$, curing temperature $(P<0.0001)$, curing duration $(P=0.0009)$, and duration of storage $(P<0.0001)$. Severity of bulb rot caused by this pathogen was also affected significantly by the two-way interaction between cultivar and curing temperature $(P<0.0001)$ but not by any other two-way interactions (data not shown). Similarly, no three-way interactions were significant (data not shown) but the four-way interaction of cultivar, curing temperature, curing duration, and duration of storage was significant $(P=0.0492)$. Redwing bulbs exhibited signifi-

Table 2. Analyses of variance (ANOVAs) for severity of bulb decay of 'Redwing' and 'Vaquero' onion inoculated with Burkholderia cepacia and B. gladioli pv. alliicola in $2009-10$ and $2010-11$ storage trials ${ }^{\mathrm{a}}$

\begin{tabular}{|c|c|c|c|c|c|c|c|c|c|c|c|c|}
\hline \multirow[b]{4}{*}{ ANOVAc $^{c}$} & \multicolumn{12}{|c|}{ Duration of storage $(1,2$, or 3 months $)$ at $5^{\circ} \mathrm{C}^{b}$} \\
\hline & \multicolumn{6}{|c|}{ B. cepacia } & \multicolumn{6}{|c|}{ B. gladioli pv. alliicola } \\
\hline & \multicolumn{3}{|c|}{ 2009-10 } & \multicolumn{3}{|c|}{ 2010-11 } & \multicolumn{3}{|c|}{ 2009-10 } & \multicolumn{3}{|c|}{ 2010-11 } \\
\hline & 1 & 2 & 3 & 1 & 2 & 3 & 1 & 2 & 3 & 1 & 2 & 3 \\
\hline \multicolumn{13}{|l|}{2 days } \\
\hline $\mathrm{Tm}$ & $<0.0001 * *$ & $0.0001 * *$ & $<0.0001^{* *}$ & $<0.0001 * *$ & $<0.0001 * *$ & $<0.0001^{* *}$ & $<0.0001 * *$ & $<0.0001 * *$ & 0.1959 & $<0.0001 * *$ & $<0.0001 * *$ & $0.0012 * *$ \\
\hline Cult & $0.0012 * *$ & $<0.0001 * *$ & $0.0015^{* *}$ & $0.0055^{* *}$ & $0.0205 *$ & $0.0026^{* *}$ & $0.0001 * *$ & $<0.0001 * *$ & $0.0056 * *$ & $0.0047 * *$ & $0.0146^{*}$ & $0.0060 * *$ \\
\hline Tm $\times$ Cult & $0.0089 * *$ & $0.0649 * *$ & $0.0484^{* *}$ & 0.5660 & 0.7448 & 0.9612 & 0.0834 & 0.6127 & $0.0006^{* *}$ & 0.4856 & 0.8688 & 0.9825 \\
\hline$R^{2}$ & 0.8431 & 0.7723 & 0.7734 & 0.1460 & 0.1388 & 0.1116 & 0.6984 & 0.6552 & 0.6562 & 0.1279 & 0.0971 & 0.0446 \\
\hline $\mathrm{CV}$ & 14.64 & 18.03 & 17.32 & 49.40 & 50.52 & 52.26 & 15.29 & 41.05 & 39.66 & 40.83 & 42.34 & 45.47 \\
\hline $\begin{array}{l}\text { Trans. } \\
14 \text { days }\end{array}$ & Sq root & Sq root & Sq root & Sq root & Sq root & Sq root & Sq root & None & None & Sq root & Sq root & Sq root \\
\hline $\mathrm{Tm}$ & $<0.0001^{* *}$ & $<0.0001 * *$ & $<0.0001 * *$ & $<0.0001^{* *}$ & $<0.0001 * *$ & 0.0511 & $<0.0001 * *$ & $<0.0001 * *$ & $<0.0001 * *$ & $<0.0001 * *$ & $<0.0001^{* *}$ & $0.0026 * *$ \\
\hline Cult & $0.0002 * *$ & $0.0024 * *$ & $0.0092 * *$ & $0.0016^{* *}$ & $0.0045^{* *}$ & $0.0152 *$ & 0.1074 & $0.0108^{*}$ & $0.0064 * *$ & $0.0114 *$ & 0.2939 & $0.0112 *$ \\
\hline Tm $\times$ Cult & 0.2426 & $0.0005^{* *}$ & $0.0144 *$ & 0.7911 & 0.6736 & $0.0021 * *$ & 0.8802 & 0.1477 & 0.4367 & 0.6542 & 0.8446 & $<0.0001 * *$ \\
\hline$R^{2}$ & 0.7523 & 0.7900 & 0.7830 & 0.2547 & 0.2564 & 0.2972 & 0.6369 & 0.6796 & 0.7015 & 0.3624 & 0.2905 & 0.3854 \\
\hline $\mathrm{CV}$ & 17.95 & 17.84 & 17.01 & 52.11 & 55.44 & 56.70 & 58.57 & 20.44 & 19.74 & 47.38 & 49.25 & 47.25 \\
\hline Trans. & Sq root & Sq root & Sq root & Sq root & Sq root & Sq root & None & Sq root & Sq root & Sq root & Sq root & Sq root \\
\hline
\end{tabular}

a A $0.5 \mathrm{ml}$ suspension of B. cepacia $\left(10^{5} \mathrm{CFU} / \mathrm{ml}\right)$ or B. gladioli pv. alliicola $\left(10^{5} \mathrm{CFU} / \mathrm{ml}\right)$ was injected into the shoulder of each onion bulb immediately after harvest, as described in the main text. Bulbs were cured at temperatures of 25 to $40^{\circ} \mathrm{C}$ for 2 or 14 days, then stored at $5^{\circ} \mathrm{C}$ for 1,2 , or 3 months. Four replications of five onion bulbs were inoculated per treatment combination per year. Onion bulbs were harvested from commercial crops of Redwing and Vaquero grown in the semiarid Columbia Basin of central Washington by the same grower-cooperator each year. Bulbs used in the 2009-10 and 2010-11 trials were produced under drip irrigation.

b $*$ and $* *=$ significant at $P=0.05$ and 0.01 , respectively.

c Bulb curing durations of 2 or 14 days. Tm $=$ curing temperature, Cult $=$ cultivar, Tm $\times$ Cult $=$ curing temperature-cultivar interaction, $R^{2}=$ coefficient of determination, and $\mathrm{CV}=$ coefficient of variance. Trans. = transformation: original data were subjected to square root (sq root) transformation because of heterogeneous variances or non-normal distribution of residuals in the ANOVA; None $=$ no transformation needed because the data met assumptions for parametric analyses. 
cantly less severe rot $(23.1 \pm 1.1 \%)$ than Vaquero bulbs $(46.0 \pm$ $1.3 \%$ ) inoculated with B. cepacia, and the severity of sour skin increased significantly with increasing postharvest curing temperature $(14.2 \pm 0.9,24.3 \pm 1.3,42.2 \pm 1.7$, and $57.6 \pm 1.8 \%$ at 25,30 , 35 , and $40^{\circ} \mathrm{C}$, respectively). The mean severity of sour skin was significantly less for bulbs cured for 2 days $(24.5 \pm 0.9 \%)$ versus 14 days $(44.8 \pm 1.4 \%)$, and increased significantly with increasing duration of storage $(27.8 \pm 1.3,35.5 \pm 1.6$, and $40.6 \pm 1.7 \%$ for 1 , 2 , and 3 months of storage, respectively).

Separate ANOVAs were calculated for each curing duration and duration of storage because of the significant four-way interaction for bulb rot severity ratings caused by B. cepacia in the 2009-10 trial (Table 2; Fig. 2). As curing temperature increased, the mean severity of bulb rot increased significantly $(P<0.0001)$ for both cultivars, regardless of the duration of postharvest curing ( 2 versus 14 days) or the duration of storage of the bulbs (Fig. 2A, C, and E). For Redwing bulbs, severity of sour skin averaged over both curing durations and all durations of storage ranged from $5.3 \pm 0.7 \%$ when cured at $25^{\circ} \mathrm{C}$ to $47.7 \pm 2.4 \%$ when cured at $40^{\circ} \mathrm{C}$ (Fig. $2 \mathrm{~A}$, $\mathrm{C}$, and $\mathrm{E}$ ); and, for Vaquero, severity of sour skin ranged from 22.9 $\pm 1.3 \%$ for bulbs cured at $25^{\circ} \mathrm{C}$ to $67.5 \pm 2.3 \%$ for bulbs cured at $40^{\circ} \mathrm{C}$ (Fig. 2). Increasing the duration of curing from 2 to 14 days also significantly increased the severity of rot for Redwing and Vaquero bulbs at all four curing temperatures, regardless of whether bulbs were stored for 1,2, or 3 months after inoculation and curing (Table 2; Fig. 2A, C, and E). The only exception was Redwing bulbs cured at $25^{\circ} \mathrm{C}$ and stored for 3 months, for which there was no significant difference in severity of rot between bulbs cured for 2 and 14 days (Fig. 2E).

2009-10 trial: B. gladioli pv. alliicola. The main effects of cultivar $(P=0.0007)$, curing temperature $(P<0.0001)$, curing duration $(P=0.0005)$, and duration of storage $(P<0.0001)$ all significantly affected severity of bulb rot. Significant two-way interactions were detected only for cultivar-curing temperature $(P$ $<0.0057)$ and curing temperature-curing duration $(P<0.0097)$. None of the three-way interactions was significant (data not shown) but the four-way interaction of cultivar, curing temperature, curing duration, and duration of storage of the bulbs was significant $(P=0.0425)$. Overall, bulbs inoculated with $B$. gladioli pv. alliicola averaged $20.7 \pm 0.6 \%$ bulb rot severity (Table 1 ). The mean severity for inoculated Redwing bulbs $(16.1 \pm 0.8 \%)$ was significantly less than that of Vaquero bulbs $(25.2 \pm 0.9 \%)$, and the severity of slippery skin increased significantly with increasing postharvest curing temperature $(10.0 \pm 0.6,13.5 \pm 0.6,21.3 \pm 0.8$, and $37.6 \pm 1.7 \%$ at $25,30,35$, and $40^{\circ} \mathrm{C}$, respectively). The mean severity of sour skin was significantly less for bulbs cured for 2 days $(14.2 \pm 0.5 \%)$ than for 14 days $(27.2 \pm 1.1 \%)$, and increased significantly with increasing duration of storage $(15.6 \pm 0.9,20.6 \pm 1.0$, and $25.9 \pm$ $1.2 \%$ for 1,2 , and 3 months of storage, respectively).
Separate ANOVAs were calculated for each curing duration and duration of storage because of significant interaction terms in the combined ANOVA for bulbs inoculated with $B$. gladioli pv. alliicola (Table 2). For both Redwing and Vaquero bulbs, the mean severity of slippery skin symptoms increased with increasing postharvest curing temperature from 25 to $40^{\circ} \mathrm{C}$ (highly significant main effect of temperature at $P<0.0001$, with no significant cultivar-curing temperature interaction), regardless of the curing duration or duration of storage of the bulbs after inoculation (Table 2; Fig. 3A, C, and E); the only exception was Redwing bulbs cured for 2 days and stored for 3 months, for which only the $40^{\circ} \mathrm{C}$ curing temperature increased severity of bulb rot significantly compared with curing at $25^{\circ} \mathrm{C}$ (highly significant cultivar-curing temperature interaction at $P=0.0006$; Fig. $3 \mathrm{E}$ ). The severity of bulb rot was significantly greater on Vaquero than Redwing bulbs (Table 3; Fig. $3 \mathrm{~A}, \mathrm{C}$, and E). For Redwing, severity of slippery skin ranged from $6.7 \pm 1.0 \%$ for bulbs cured at $25^{\circ} \mathrm{C}$ to $31.7 \pm 2.3 \%$ for bulbs cured at $40^{\circ} \mathrm{C}$; and, for Vaquero, slippery skin severity ranged from 13.3 $\pm 0.7 \%$ for bulbs cured at $25^{\circ} \mathrm{C}$ to $43.5 \pm 2.4 \%$ for bulbs cured at $40^{\circ} \mathrm{C}$. Increasing the duration of curing from 2 to 14 days significantly increased severity of bulb rot for both cultivars regardless of whether bulbs were stored for 1, 2, or 3 months (Table 2; Fig. 3A, $\mathrm{C}$, and $\mathrm{E}$ ). This effect of a longer curing duration enhancing bulb rot severity was more pronounced the higher the curing temperature.

2010-11 trial: B. cepacia. Severity of bulb rot caused by $B$. cepacia was influenced significantly by the main effects of cultivar $(P<0.0004)$, curing temperature $(P<0.0001)$, and curing duration $(P<0.0065)$ but not duration of storage $(P=0.0707)$. The only significant two-way interaction was between curing temperature and curing duration $(P=0.0081)$. Significant three-way interactions were detected for cultivar, curing temperature, and curing duration $(P=0.0046)$ and for cultivar, curing temperature, and duration of storage $(P=0.0054)$. The four-way interaction was not significant $(P=0.3866)$. Averaged over cultivars, curing durations, curing temperatures, and durations of storage, bulbs inoculated with $B$. cepacia displayed $39.8 \pm 1.0 \%$ severity of sour skin, which was about 5\% greater than the 2009-10 trial (Table 1). Redwing bulbs exhibited significantly less severe rot $(29.2 \pm 1.2 \%)$ than Vaquero bulbs $(50.0 \pm 1.4 \%)$, and the severity of sour skin increased significantly with increasing postharvest curing temperature $(16.0 \pm 0.8,28.5 \pm 1.4,48.2 \pm 1.8$, and $65.0 \pm 1.9 \%$ at 25,30 , 35 , and $40^{\circ} \mathrm{C}$, respectively). The mean severity of sour skin was significantly less for bulbs cured for 2 days $(28.6 \pm 0.9 \%)$ than for 14 days $(51.8 \pm 1.6 \%)$, and increased significantly with increasing duration of storage $(38.6 \pm 1.6,40.0 \pm 1.7$, and $41.2 \pm 1.9 \%$ for 1 , 2 , and 3 months of storage, respectively).

Separate ANOVAs were calculated for each curing duration and duration of storage for bulbs inoculated with $B$. cepacia in the
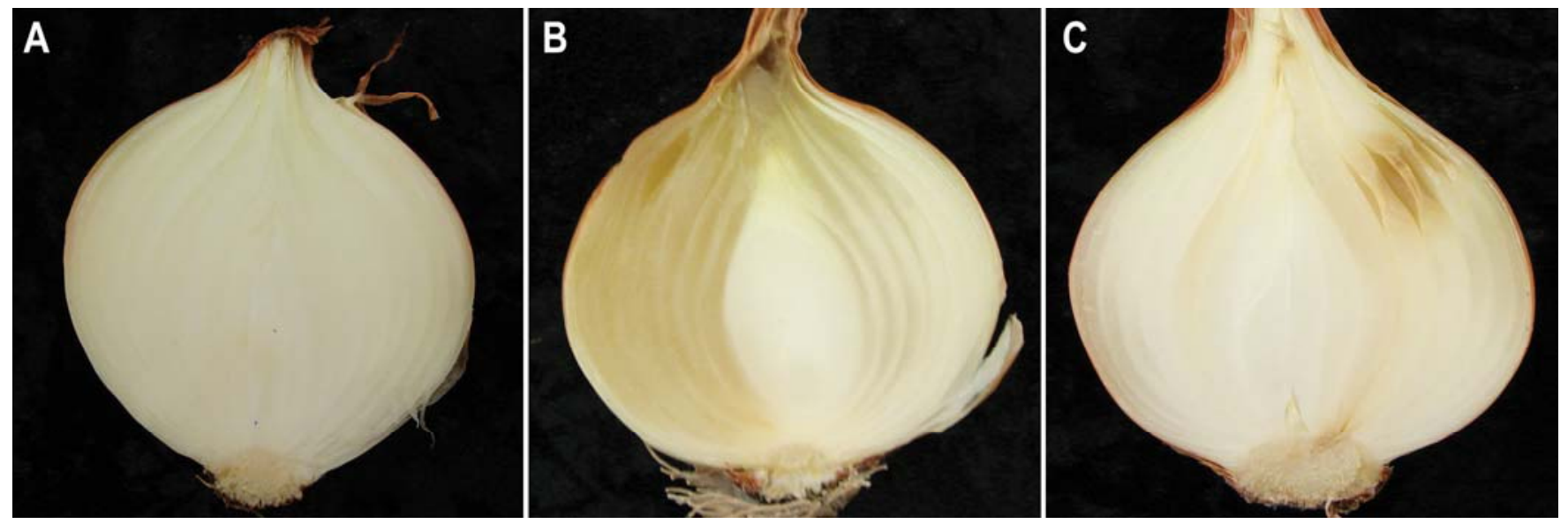

Fig. 1. Symptoms of bulb rot on 'Vaquero' onion following injection with A, sterile distilled water; B, Burkholderia cepacia; or C, B. gladioli pv. alliicola, curing the bulbs at $30^{\circ} \mathrm{C}$ for 14 days, and storing the bulbs for 2 months at $5^{\circ} \mathrm{C}$. Each bulb was then cut down the center from the neck to the basal plate through the injection site on the shoulder of the bulb. 
2010-11 trial because of significant interactions in the combined ANOVA for bulb rot severity ratings (Table 2). In the ANOVA for each curing duration and duration of storage, except that of bulbs cured for 14 days and stored for 3 months, the main effects of cultivar and temperature were significant but the interaction was not significant (Table 2). For both cultivars, the severity of bulb rot increased significantly with increasing curing temperature but sour skin was more severe in bulbs of Vaquero than bulbs of Redwing (Fig. 2B, D, and F). The significant interaction between cultivar and curing temperature for bulbs cured for 14 days and stored for 3 months is illustrated by the lines shown in Figure $2 \mathrm{~F}$ for Vaquero versus Redwing bulbs (i.e., the increase in severity of sour skin with increasing curing temperature was much greater for Vaquero than Redwing). For Redwing, severity of sour skin ranged from 9.1 $\pm 0.8 \%$ for bulbs cured at $25^{\circ} \mathrm{C}$ to $56.3 \pm 2.6 \%$ for bulbs cured at $40^{\circ} \mathrm{C}$; and, for Vaquero, severity ranged from $22.2 \pm 1.1 \%$ for bulbs cured at $25^{\circ} \mathrm{C}$ to $72.6 \pm 2.6 \%$ for bulbs cured at $40^{\circ} \mathrm{C}$ (Table 2; Fig. 2). Increasing the duration of curing from 2 to 14 days significantly increased severity of bulb rot for both cultivars at all curing temperatures, regardless of how long the bulbs were stored after inoculation and curing (Fig. 2B, D, and F).

2010-11 trial: B. gladioli pv. alliicola. Inoculation of onion bulbs with $B$. gladioli pv. alliicola resulted in significant main effects of cultivar $(P<0.0020)$, curing temperature $(P<0.0001)$, curing duration $(P=0.0044)$, and duration of storage $(P=0.0021)$ for severity of bulb decay in the ANOVA. Significant two-way interactions were detected between cultivar and curing temperature $(P=0.0021)$, cultivar and duration of storage $(P=0.0445)$, curing

\section{9-10 trial}

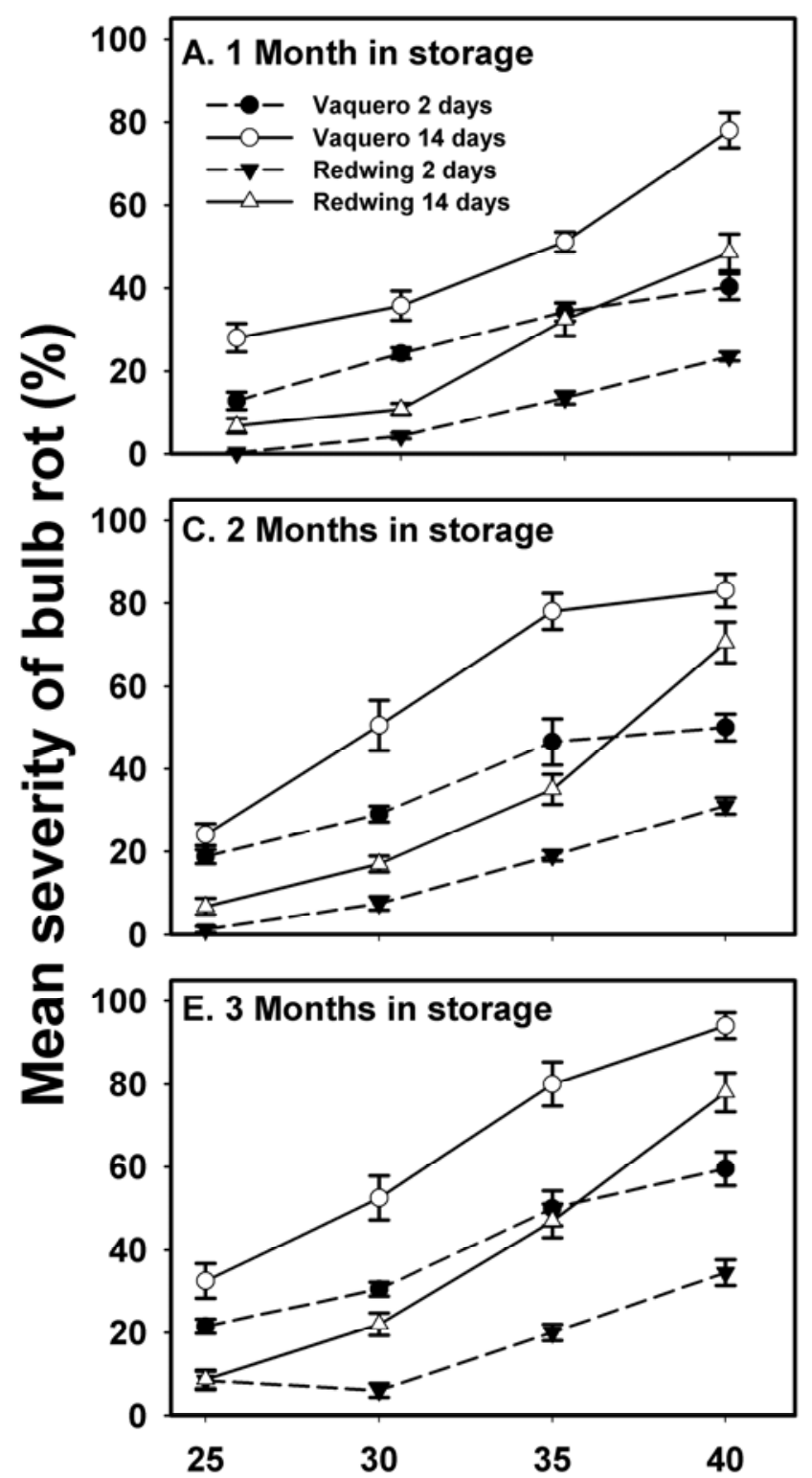

\section{0-11 trial}
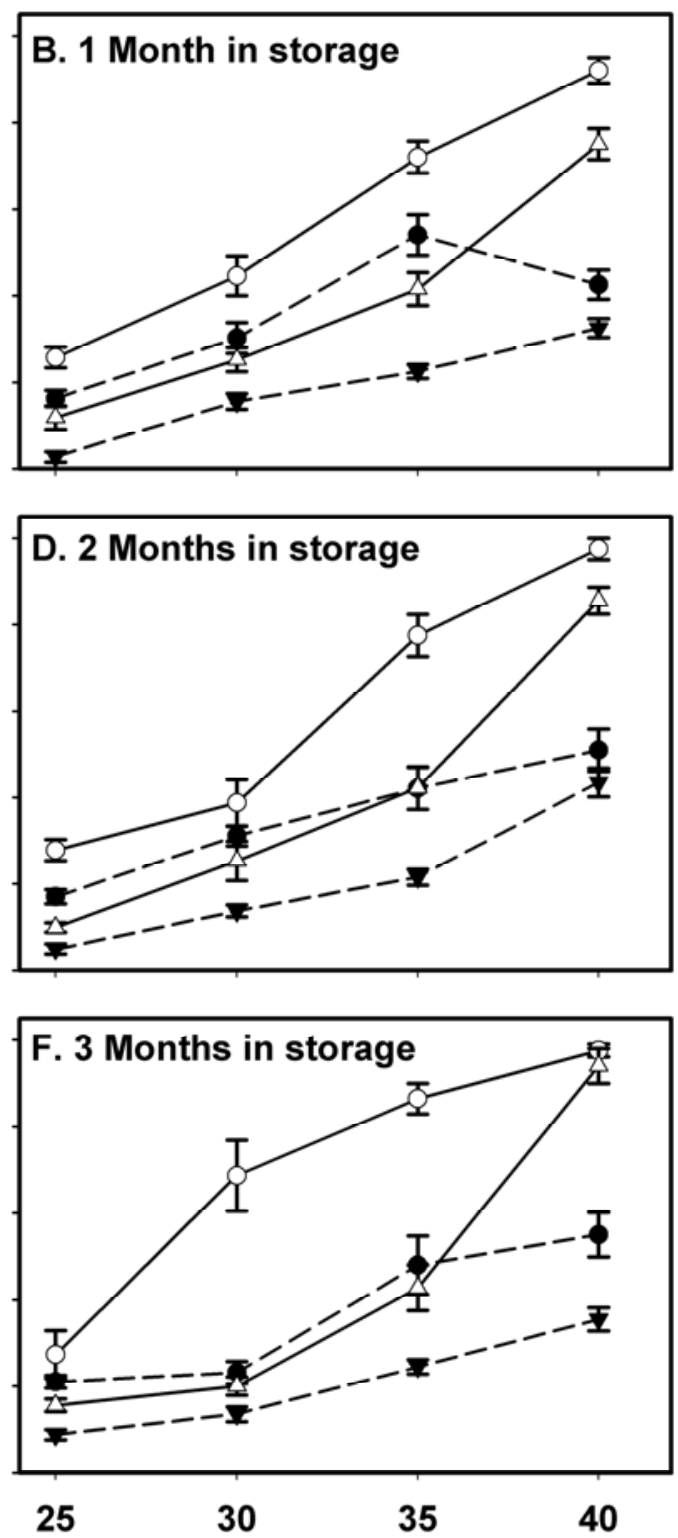

25

30

40

\section{Curing temperature $\left({ }^{\circ} \mathrm{C}\right)$}

Fig. 2. Mean severity of onion bulb rot caused by Burkholderia cepacia in storage trials in A, C, and E, 2009-10 and B, D, and F, 2010-11 with 'Redwing' and 'Vaquero' onion. Each bulb was inoculated with B. cepacia (approximately $5 \times 10^{4} \mathrm{CFU}$ ), cured at $25,30,35$, or $40^{\circ} \mathrm{C}$ for 2 or 14 days, then stored at $5^{\circ} \mathrm{C}$ for $\mathbf{A}$ and $\mathbf{B}, 1$ month; $\mathbf{C}$ and D, 2 months; or $E$ and F, 3 months. Each bulb was then cut down the center from the neck to the basal plate through the injection site on the shoulder of the bulb, to assess severity of bulb rot (percentage of the cut surface area of fleshy scales exhibiting symptoms typical of bulb decay). Each data point shows the mean and standard error of the severity of bulb rot for four replications of five bulbs. 
temperature and curing duration $(P<0.0001)$, curing temperature and duration of storage $(P=0.0026)$, and curing duration and duration of storage $(P=0.0154)$. Significant three-way interactions were observed among cultivar, curing temperature, and curing duration $(P=0.0004)$; cultivar, curing temperature, and duration of storage $(P=0.0039)$; and cultivar, curing duration, and duration of storage $(P=0.0389)$. The four-way interaction was not significant $(P=0.2435)$. Overall, bulbs inoculated with the slippery skin pathogen averaged $27.4 \pm 0.7 \%$ severity of bulb rot (Table 1 ), which was about $6 \%$ more severe than in the 2009-10 trial. Redwing bulbs exhibited significantly less severe rot $(22.3 \pm 1.0 \%)$ than Vaquero bulbs $(32.1 \pm 1.0 \%)$. Similar to the 2009-10 trial, the severity of slippery skin symptoms increased with increasing postharvest curing temperature $(14.8 \pm 0.6,19.1 \pm 0.6,24.6 \pm 0.8$, and
$51.0 \pm 2.0 \%$ at $25,30,35$, and $40^{\circ} \mathrm{C}$, respectively). The mean severity of bulb rot was significantly less in bulbs cured for 2 days $(20.0 \pm 0.5 \%)$ than for 14 days $(35.0 \pm 1.3 \%)$. Although there was no significant difference in severity of slippery skin for bulbs stored for 2 versus 3 months $(28.1 \pm 1.3$ and $28.8 \pm 1.2 \%$ severity rating, respectively), bulbs stored for 1 month had significantly less severe rot $(25.2 \pm 1.3 \%)$.

Based on significant interaction terms in the combined ANOVA for bulb rot severity ratings, separate ANOVAs were calculated for curing duration and duration of storage for bulbs inoculated with B. gladioli pv. alliicola in the 2010-11 trial (Table 2). For both Redwing and Vaquero bulbs, mean severity of slippery skin increased with increasing postharvest curing temperature from 25 to $40^{\circ} \mathrm{C}$ (highly significant main effect of temperature, regardless of

\section{9-10 trial}

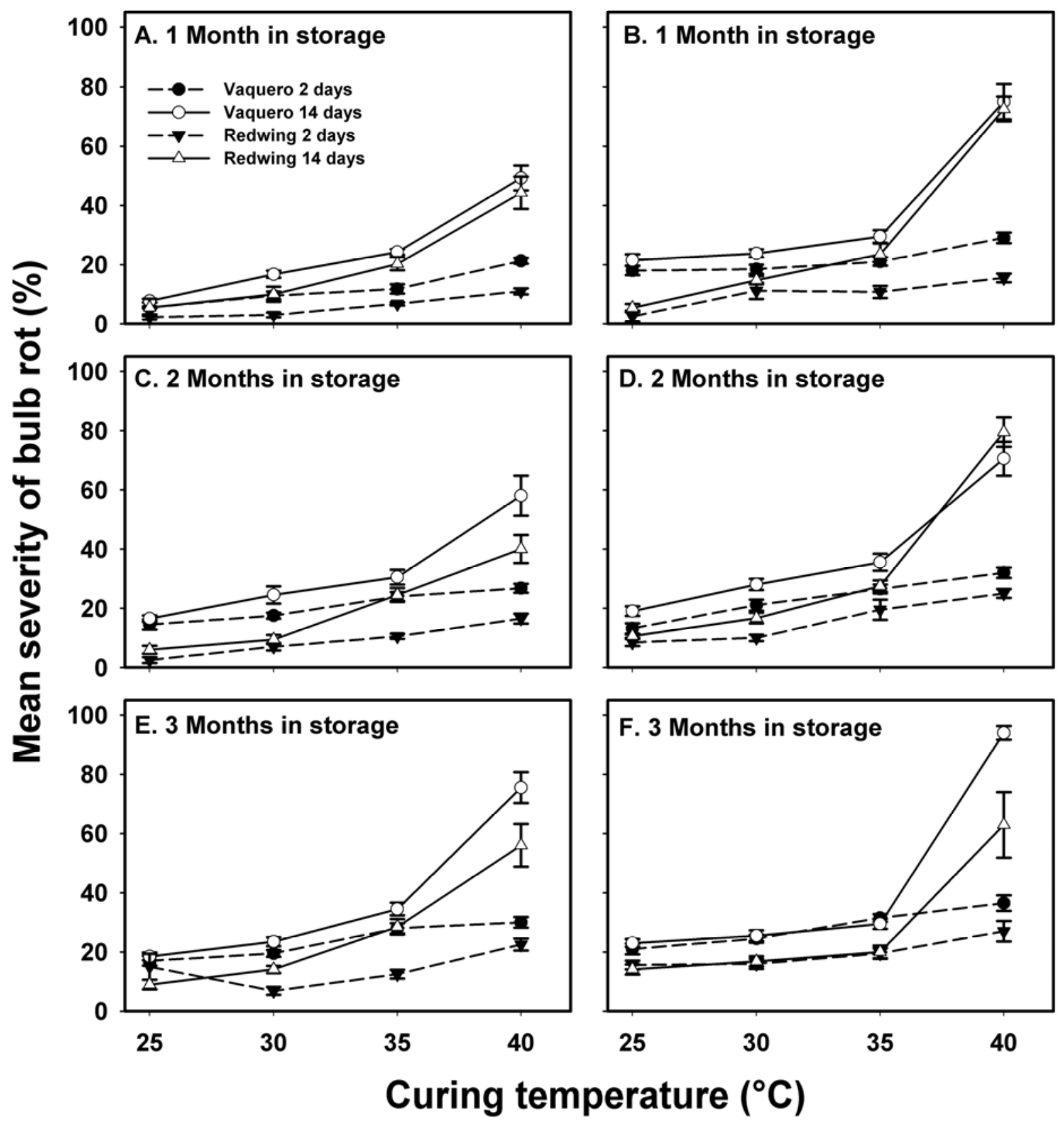

Fig. 3. Mean severity of onion bulb rot caused by Burkholderia gladioli pv. alliicola in storage trials in A, C, and E, 2009-10 and B, D, and F, 2010-11 with 'Redwing' and 'Vaquero' onion. Each bulb was inoculated with B. gladioli pv. alliicola (approximately $5 \times 10^{5} \mathrm{CFU}$ ), cured at $25,30,35$, or $40^{\circ} \mathrm{C}$ for 2 or 14 days, and then stored at $5^{\circ} \mathrm{C}$ for $\mathbf{A}$ and B, 1 month; $\mathbf{C}$ and $\mathbf{D}, 2$ months; or $\mathbf{E}$ and F, 3 months. Each bulb was then cut down the center from the neck to the basal plate through the injection site on the shoulder of the bulb, to assess severity of bulb rot (percentage of the cut surface area of fleshy scales exhibiting symptoms typical of bulb decay). Each data point shows the mean and standard error of the severity of bulb rot for four replications of five bulbs. 
the curing duration or duration of storage of the bulbs after inoculation; Table 2; Fig. 3B, D, and F). Severity of bulb rot was always significantly greater on Vaquero than Redwing bulbs, except when bulbs were cured for 14 days at $40^{\circ} \mathrm{C}$ and then stored for 2 months (Table 2; Fig. 3D). For Redwing, severity of slippery skin ranged from $9.6 \pm 0.7 \%$ for bulbs cured at $25^{\circ} \mathrm{C}$ to $45.1 \pm 3.0 \%$ for bulbs cured at $40^{\circ} \mathrm{C}$; and, for Vaquero, severity ranged from $19.3 \pm$ $0.7 \%$ for bulbs cured at $25^{\circ} \mathrm{C}$ to $56.2 \pm 2.7 \%$ for bulbs cured at $40^{\circ} \mathrm{C}$. When bulbs were stored for 1 or 2 months after inoculation and curing, the longer curing duration (14 versus 2 days) increased severity of bulb rot at each curing temperature for both cultivars, and the increase in bulb rot severity associated with the longer curing duration was particularly pronounced at the highest curing temperature $\left(40^{\circ} \mathrm{C}\right.$; Table 2; Fig. $3 \mathrm{~B}$ and $\left.\mathrm{D}\right)$. When bulbs were stored for 3 months, the longer curing duration only increased severity of bulb rot when bulbs were cured at $40^{\circ} \mathrm{C}$, for both Redwing and Vaquero (Fig. 3F).

Correlation coefficients. The correlation of mean bulb rot severity ratings in the 2009-10 trial versus the 2010-11 trial was highly significant when onion bulbs were inoculated with $B$. серacia: $r=0.7519(P<0.0001)$ for both cultivars, $r=0.6269(P<$ $0.0001)$ for Redwing, and $r=0.7848$ ( $P<0.0001)$ for Vaquero (Fig. 4A). Similarly, for onion bulbs inoculated with $B$. gladioli pv. alliicola, the correlation of mean bulb rot severity ratings in the 2009-10 trial versus the 2010-11 trial was highly significant: $r=$ $0.7736(P<0.0001)$ for both cultivars, $r=0.6254(P<0.0001)$ for
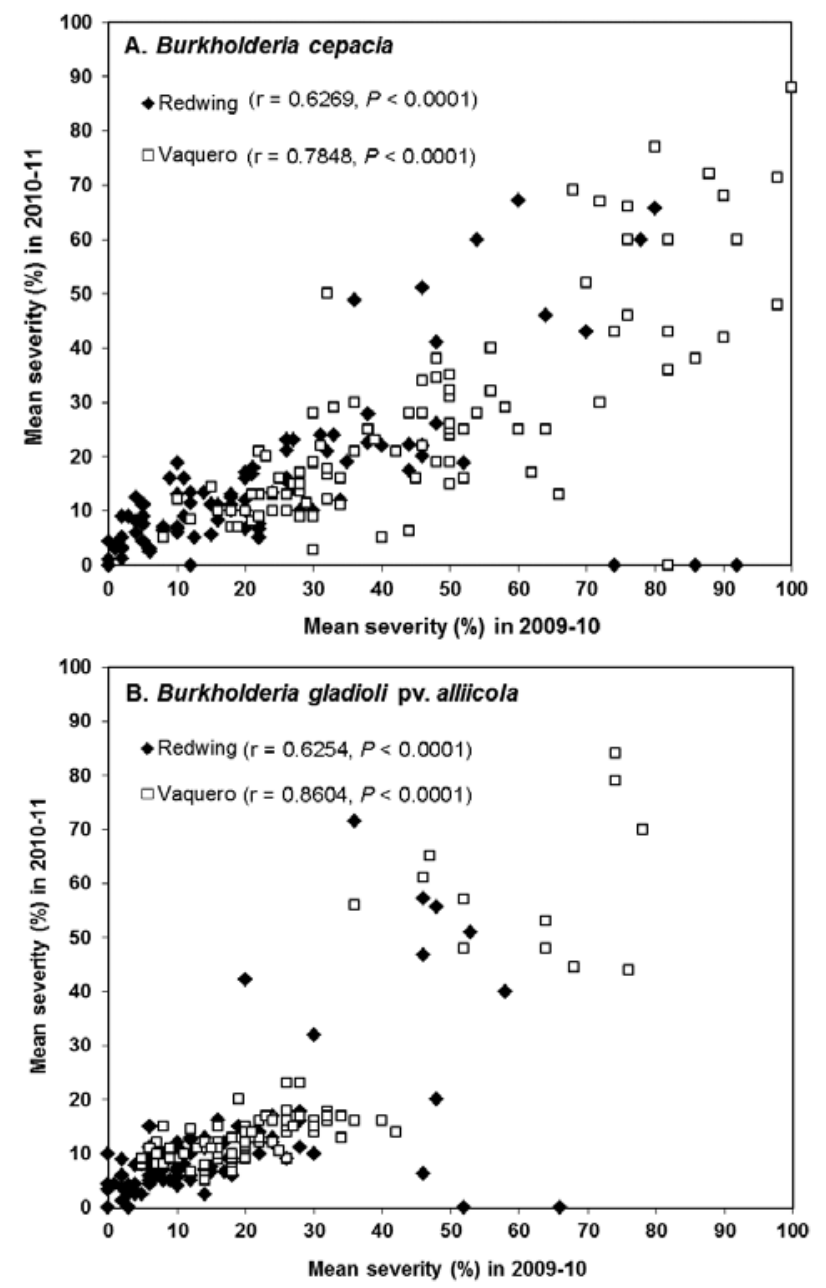

Fig. 4. Correlation coefficients for mean severity of bulb rot in a 2009-10 trial versus a 2010-11 trial for bulbs of 'Redwing' and 'Vaquero' onion inoculated with A, Burkholderia cepacia or B, B. gladioli pv. alliicola at harvest and then subjected to four postharvest curing temperatures, two curing durations, and three durations of storage (refer to the main text for details). Each data point is the mean of four replications of five bulbs.
Redwing, and $r=0.8604$ ( $P<0.0001)$ for Vaquero (Fig. 4B). The results demonstrate the consistency in reaction of onion bulbs of Redwing and Vaquero to the slippery skin and sour skin pathogens under the postharvest curing parameters and durations of storage evaluated in this study. Interestingly, the correlation coefficients for bulb rot severity ratings caused by $B$. cepacia versus $B$. gladioli $\mathrm{pv}$. alliicola within each trial were also highly significant: $r=0.8446$ $(P<0.0001)$ in the $2009-10$ trial and $r=0.85017(P<0.0001)$ in the 2010-11 trial (calculated across both cultivars), suggesting that the nature of the bulb-pathogen interactions is similar for B. cepacia and B. gladioli pv. alliicola.

\section{Discussion}

In this study, several onion bulb postharvest curing and storage parameters that growers can manipulate were evaluated to assess the potential influence on severity of bulb rots caused by $B$. cepacia and B. gladioli pv. alliicola, for two onion cultivars commonly grown in the semiarid Pacific Northwest region of the United States. The results demonstrated clearly that postharvest curing temperature, curing duration, and duration of storage of onion bulbs inoculated with $B$. cepacia or B. gladioli pv. alliicola significantly affected the severity of bulb rot in each of two seasons, regardless of the conditions in the commercial onion crops from which the bulbs were harvested. For both pathogens, the most severe bulb rot was observed when bulbs were cured at the highest temperature evaluated $\left(40^{\circ} \mathrm{C}\right)$ prior to cold storage. This effect was exacerbated by a curing duration of 14 days compared with 2 days, and by an increased storage time for the bulbs after curing (1,2, or 3 months).

When onion bulbs were inoculated with the slippery skin pathogen, B. gladioli pv. alliicola, and cured for 2 days, bulb rot in storage was least severe at curing temperatures $\leq 35^{\circ} \mathrm{C}$. Increasing the duration of curing to 14 days increased the severity of slippery skin in storage, particularly if bulbs were cured at $40^{\circ} \mathrm{C}$. When onion bulbs were inoculated with the sour skin pathogen, B. cepacia, the severity of bulb rot in storage was much greater than that of bulbs inoculated with $B$. gladioli pv. alliicola, even though a 10 -fold higher inoculum concentration was used with the latter pathogen compared with $B$. cepacia. Furthermore, increasing the curing temperature and duration caused an even greater increase in the severity of sour skin that developed in storage compared with the effects on slippery skin. These results indicate that postharvest curing temperatures and durations used in onion storage facilities can play a significant role in reducing losses to slippery skin and sour skin in storage but are even more critical for management of sour skin caused by $B$. cepacia than slippery skin caused by $B$. gladioli pv. alliicola. Although curing onion bulbs at temperatures $>30^{\circ} \mathrm{C}$ for longer than 2 days produces the tight wrapper skins and dried necks needed to reduce losses to shrinkage or Botrytis neck rot in storage, such high temperatures and extended durations of curing promote development of storage rots in bulbs latently infected with B. cepacia or B. gladioli pv. alliicola at harvest.

Development of sour skin and slippery skin in bulbs of Redwing and Vaquero onion in this study was similar to the results observed with the same cultivars inoculated with $E$. cloacae in a previous study (14). In both studies, the most severe bulb rot was observed when inoculated bulbs were cured at 35 or 40 versus 25 or $30^{\circ} \mathrm{C}$ prior to cold storage, in bulbs cured for 14 versus 2 days, and the longer the bulbs were stored after curing ( 3 versus 1 or 2 months). The results of both studies suggest that, similar to observations in the E. cloacae study, management of bulb rots caused by B. cepacia and $B$. gladioli pv. alliicola can be improved by using curing temperatures $\leq 35^{\circ} \mathrm{C}$ and limiting the curing duration to 2 days instead of 14 days (although in neither study were intermediate curing durations evaluated, between 2 and 14 days).

In the 2009-10 and 2010-11 trials in this study, the severity of bulb rot resulting from inoculating bulbs with $B$. cepacia was greater than the severity of bulb rot in bulbs inoculated with $B$. gladioli pv. alliicola, despite the fact that 10 -fold less inoculum was used for B. cepacia than for B. gladioli pv. alliicola. This illustrates the much more aggressive nature of the sour skin pathogen 
compared with the slippery skin pathogen. In a similar study completed with E. cloacae (14), an even greater inoculation rate was used for that pathogen compared with the slippery skin pathogen in this study (approximately $5 \times 10^{7} \mathrm{CFU}$ ), resulting in less symptom development and demonstrating that the relative aggressiveness of B. cepacia is much greater than that of B. gladioli pv. alliicola, and the latter is much greater than that of E. cloacae.

In this study, onion bulbs of Redwing developed significantly less severe bulb decay than bulbs of Vaquero when inoculated with either B. cepacia or B. gladioli pv. alliicola. This supports previous observations of the greater susceptibility of Vaquero than Redwing to bacterial bulb rot pathogens. Schroeder et al. (15) inoculated onion bulbs of 43 medium- to long-day-length onion storage cultivars with B. cepacia, B. gladioli pv. alliicola, and E. cloacae to assess the diversity of potential resistance among the cultivars to these storage rot pathogens in the semiarid Columbia Basin of central Washington State. Redwing ranked among the top three least-susceptible cultivars to all three bacterial pathogens, whereas Vaquero ranked 22nd, 18th, and 13th least-susceptible of the 43 cultivars evaluated in terms of mean severity of bulb rot caused by B. cepacia, B. gladioli pv. alliicola, and E. cloacae, respectively. This differential response of Redwing versus Vaquero was also observed in a previous study in which E. cloacae was inoculated into bulbs of Redwing and Vaquero and evaluated for response to curing temperature and curing duration (14), and in previous field trials evaluating onion storage cultivars for resistance to Enterobacter bulb decay caused by E. cloacae (16). In both studies, Redwing bulbs exhibited less severe bulb rot than Vaquero bulbs when inoculated with E. cloacae at harvest and stored in a commercial storage facility for up to 4 months. Collectively, these studies demonstrate consistency in the relative susceptibility of the two cultivars to the three bacterial pathogens regardless of the conditions of the onion crops from which the bulbs were harvested or postharvest curing parameters evaluated. In each study, the onion crops were grown in the Columbia Basin on sandy loam soils, using center-pivot or drip irrigation (14-16).

As demonstrated in previous studies, injection of water into an onion bulb can increase the incidence or severity of bacterial storage rots $(14,16)$. In this study, 6.2 and $10.1 \%$ of onion bulbs injected with sterile water in the 2009-10 and 2010-11 seasons, respectively, developed symptoms of bacterial storage rots, compared with 4.0 and $4.5 \%$ of noninoculated bulbs in 2009-10 and 2010-11, respectively. The incidence of bulb rot in the noninoculated bulbs most likely reflects the incidence of bulbs infected naturally with bacterial pathogens in the commercial onion crops from which the bulbs were harvested for this study. The results were similar to 5.8 and $6.1 \%$ storage rots observed for bulbs injected with water, and 0.5 and $3.9 \%$ of noninoculated bulbs that developed bacterial rots in each of two seasons in a related postharvest bulb curing study with E. cloacae (14). In both studies, the incidence of noninoculated bulbs that developed bacterial storage rots was significantly less than that of bulbs injected with water. Natural, latent bacterial infections in the bulbs at harvest may be stimulated by water injected into the bulbs to become active in storage, or pathogens could be introduced into the bulb as the needle passes through the outer dry scales.

Injection was used to inoculate onion bulbs in this study because of the efficiency of this method for evaluating large numbers of bulbs (14-16). However, a less-invasive inoculation method might avoid circumventing potential resistance mechanisms associated with movement of the pathogen from the foliage down the neck and into the bulb, and permit evaluation of the effects of curing parameters on incidence as well as severity of bulb rot. This is very relevant because any bulb with a severity rating $>0$ would be rejected from commercial onion markets. A more natural method of inoculation, such as spraying a suspension of $B$. cepacia and $B$. gladioli pv. alliicola onto onion plants in the field prior to harvest, could be used for this kind of study. However, foliar applications of opportunistic human pathogens such as B. cepacia and B. gladioli pv. alliicola onto grower-cooperator crops could potentially pose food safety risks $(7,13)$. Instead, injecting onion bulbs with $B$. cepacia and B. gladioli pv. alliicola after the bulbs were removed from the fields provided an effective method of evaluating the potential impact of postharvest curing parameters on severity of bacterial storage rots.

The results of this study demonstrate that the severity of sour skin and slippery skin in onion storage facilities can potentially be minimized by using relatively low postharvest curing temperatures $\left(<35^{\circ} \mathrm{C}\right)$ and short curing durations (approximately 2 days). Furthermore, if there is a perceived high risk of bacterial infection of onion bulbs close to harvest (e.g., unseasonal precipitation close to harvest when the bulbs and necks should be drying), particular attention could be paid to postharvest curing parameters and the duration of storage of the bulbs to reduce the risk of bacterial bulb rots in storage.

\section{Acknowledgments}

This project was supported by the Department of Plant Pathology (PPNS Number 0591) in the Washington State University College of Agricultural, Human and Natural Resource Sciences, and the Washington State University Agricultural Research Center for CRIS Project Number WNPOO652. We thank the Pacific Northwest Vegetable Association, the Washington State Commission for Pesticide Registration, United States Department of Agriculture (USDA) Western Region Integrated Pest Management Competitive Grants Program, and USDA-NIFA Specialty Crop Research Initiative Number 2010-01193 for financial support for this project. Invaluable in-kind support was provided by L\&L Ag Production in the form of onion bulbs for storage evaluations. We thank C. Armstrong, S. Hulbert, and T. Murray for critical review of the manuscript prior to submission; and J. Dung, A. Bates, S. Dossey, J. Pena, and N. Peterson for providing technical support.

\section{Literature Cited}

1. Anonymous. 2004-2011. Agricultural prices for onions. http://www.nass. usda.gov

2. Brady, C. L., Goszczynska, T., Venter, S. N., Cleenwerck, I., De Vos, P. Gitaitis, R. D., and Coutinho, T. A. 2011. Pantoea allii sp. nov., isolated from onion plants and seed. Int. J. Syst. Evol. Microbiol. 61:932-937.

3. Brewster, J. L. 2006. Onions and Other Vegetable Alliums. Crop Production Science in Horticulture Series No. 3. CAB International, Wallingford, UK.

4. Burkholder, W. H. 1942. Three bacterial plant pathogens: Phytomonas caryophylli sp. n., Phytomonas alliicola sp. n., and Phytomonas manihotis (Athaud-Berthet et Bondar) Viegas. Phytopathology 32:141-149.

5. Burkholder, W. H. 1950. Sour skin, a bacterial rot of onion bulbs. Phytopathology 40:115-117.

6. Ceponis, M. J., Cappellini, R. A., and Lightner, G. W. 1986. Disorders in onion shipments to the New York market, 1972-1984. Plant Dis. 70:988-991.

7. Clementino, M. M., de Filippis, I., Nascimento, C. R., Branquinho, R., Rocha, C. L., and Martins, O. B. 2001. PCR analyses of tRNA intergenic spacer, 16S-23S internal transcribed spacer, and randomly amplified polymorphic DNA reveal inter- and intraspecific relationships of Enterobacter cloacae strains. J. Clin. Microbiol. 39:3865-3870.

8. DeFrancesco J. 2004. 2004 Pest Management Strategic Plan for Dry Bulb Storage Onions in Colorado, Idaho, Oregon, Utah, and Washington. USDA Western Integrated Pest Management Center. http://www.ipmcenters.org/ pmsp/pdf/WesternONION.pdf

9. Holt, J. G., Krieg, N. R., Sneath, P. H. A., Staley, J. T., and Williams, S. T. 1994. Bergey's Manual of Determinative Bacteriology, 9th ed. The Williams \& Wilkins Co., Baltimore, MD.

10. Kawamoto, S. O., and Lorbeer, J. W. 1972. Multiplication of Pseudomonas cepacia in onion leaves. Phytopathology 62:1263-1265.

11. Kawamoto, S. O., and Lorbeer, J. W. 1974. Infection of onion leaves by Pseudomonas cepacia. Phytopathology 64:1440-1445.

12. Pelter, G. Q., and Sorensen, E. J. 2004. Crop profile for onions in Washington. USDA National Information System Pest Management Center.

13. Sanders, W. E., and Sanders, C. C. 1997. Enterobacter spp.: pathogens poised to flourish at the turn of the century. Clin. Microbiol. Rev. 10:220-241.

14. Schroeder, B. K., and du Toit, L. J. 2010. Effects of postharvest onion curing parameters on Enterobacter bulb decay in storage. Plant Dis. 94:1425-1430.

15. Schroeder, B. K., Humann, J. L., Waters, T. D. Wohleb, C. H., Derie, M. L. and L. J. du Toit. 2010. Evaluation of onion cultivars for resistance to three bacterial storage rot pathogens in Washington State, 2010. Plant Dis. Manage. Rep. 4:V113. Online publication. doi:10.1094/PDMR04

16. Schroeder, B.K., Waters, T., and du Toit, L. J. 2010. Evaluation of onion cultivars for resistance to Enterobacter cloacae in storage. Plant Dis. 94:236-243.

17. Schwartz, H. F., and Mohan, S. K. 2008. Compendium of Onion and Garlic Diseases and Pests, 2nd ed. American Phytopathological Society, St. Paul, MN.

18. Teviotdale, B. L. Davis, R. M., Guerard, J. P., and Harper, D. H. 1989. Effect of irrigation management on sour skin of onion. Plant Dis. 73:819-822.

19. Vidaver, A. K. 1967. Synthetic and complex media for the rapid detection of fluorescence of phytopathogenic pseudomonads: effect of the carbon source. Appl. Microbiol. 15:1523-1524. 